To cite this article: Păcurar, E. \& Mihele, R. (2020). Language Instruction in Tourism Education: Beyond the Vocational Field. Romanian Review of Geographical Education, 9(2), 5-22. DOI: 10.24193/RRGE220201

\title{
LANGUAGE INSTRUCTION IN TOURISM EDUCATION: BEYOND THE VOCATIONAL FIELD
}

\author{
ELENA PĂCURAR \\ Babeş-Bolyai University, Faculty of Letters, Department of Foreign Languages for Specific Purposes, Cluj- \\ Napoca, Romania, e-mail: elenavoj@gmail.com
}

ROXANA MIHELE

Babeş-Bolyai University, Faculty of Letters, Department of Foreign Languages for Specific Purposes, ClujNapoca, Romania, e-mail: mihele.m.roxana@gmail.com

(Received: July 2020; in revised form: August 2020)

\begin{abstract}
The paper reports on the quantitative data resulting from the questionnaires designed by the authors (language for specific purposes instructors) addressing both graduate students' range of abilities, skills and competences and tourism employers' expectations. Language proficiency and communicative competence (understood as specific purpose language ability) are discussed as indicative of graduate students' rate of employment in their field of studies. The authors choose tourism graduate students as the focus group in their investigation of the possible factors impacting market employability and influencing the degree of socioprofessional integration in Cluj county.
\end{abstract}

Keywords: language proficiency, communicative competence, soft skills, graduate students, employability, employment

\section{NTRODUCTI ON}

Situated at the convergence of different fields of expertise and domains, the area of languages for specific purposes (LSP) is subject to rapid changes and claims on the part of the many stakeholders involved in the decision-making process regarding language policy documents that would impact both the public sector (state-budgeted higher education institutions seen as generators of workforce) and the private sector (the employer market recruiting workforce). Thus, a discussion about the profile of graduate students in the Romanian education system, the expectations of the labour market and the flexibility of the academic curriculum is welcome especially in light of the recent pandemic affecting most service sectors, tourism in particular. 
The authors of this paper acknowledge their privileged position in identifying the various perspectives brought together here and mediating between the parts involved; the syllabus of LSP subjects best reflects the needs of the (under) graduate students, part of the core skills expected from the employer market (especially those related to professional communication) and the generic academic/study skills standardised by the higher education institutions in question.

A selection of the most important conclusions formulated in the 2019 UNWTO Report on "The Future of Work and Skills Development in Tourism" will set the background for our extended analysis: the key competences triggered by the shifting pace of job development are "customer focus, creativity and innovation"; the public sector has an undeniably important role in supporting employment in tourism; policy makers should foster lifelong learning, "from basic to the most complex skills, such as technical and soft skills" (UNWTO Report, 2019, p. 8).

\section{TERATURE REVI EW}

The UNWTO Report raises a debatable issue in the form of guidelines for future professionals: the (continuous) development of lifelong skills is critical against the reminder that "the 'finish studying to start working' paradigm is no longer valid" (UNWTO Report, 2019, p. 9). Furthermore, tertiary education is currently envisioned as only a part of the more complex spectrum of professional instruction:

"In a time when - as the cliché has it - the half-life of knowledge is steadily decreasing, and the virtues of lifelong learning are asserted, it makes little sense to think of the first degree as being more than the first step on the pathways that graduates subsequently take. 'Learning how to learn' is increasingly recognized as an important metacognitive achievement that is central to continuing personal and professional development" (Knight \& Yorke, 2003, p. 11).

While it is becoming obvious that certain vocational fields value practical instruction and training more than (theoretical) knowledge, a preoccupation for the relevance, role and impact of tourism education in an academic context still remains, whenever the issue of employment is accompanied by the debate between experience vs. education. This, in turn, interrogates the practical nature of narrow LSP subjects (e.g. English for Tourism) against the (more generic) range of skills and competences considered key for future professional success and development.

Tourism education is largely considered to be a response to the threefold need: "the need to promote individual development, the need to advance knowledge and the need to be practical and relevant to industry" (Riley, Ladkin \& Szivas, 2002, p. 171). While, nowadays, an important generator of knowledge growth comes from within the "innovative workplace" sphere promoting the learning-by-doing approach, the other 
invaluable source is the higher education system (Knight \& Yorke, 2003, p. $3)$, as education remains "the major platform for the development of human capital for the industry" especially in connection to the more complex occupations targeted by graduate students (e.g. tourism management, tourism marketing - Riley, Ladkin \& Szivas, 2002, p. 171).

Whether the academic curricula have been designed "in response" to the market demand or not has been the object of sustained research supported by the academic body and professional community alike. The range of expectations that the employers have of university graduates varies from country to country, but most businesses mention (in various priority ratings) "a wide range of transferable, 'soft' skills such as selfmanagement, communication and teamworking" (McKinnon qtd. in Ryan, 2013 , p. 212). Are these transferable, $21^{\text {st }}$ century skills currently included as such in the vocational curriculum in Romania (in the core or optional subjects)? - this question is still to be answered. The authors of the present paper can only account for the curricular content of LSP subjects, where certain transversal and transferable skills (e.g. intercultural communication, critical thinking, collaborative skills, etc.) feature in the description of specialised language courses.

As tourism education focuses on a wide range of learning outcomes, a complete and exhaustive alignment of curricular design and market demand is seen as not only impossible, or rather (not entirely) necessary:

"A total overlap between education and job descriptions is unrealistic and
probably undesirable in the light of progress and change. As the industry
grows and changes, new roles will emerge and old roles take on new
responsibilities" (Riley, Ladkin \& Szivas, 2002, p. 173).

If academic tourism education wishes to be truly innovative, it might consider complementing its responsive/reactive vision with a proactive one and try to anticipate rather than merely react to change. When, at the level of transversal academic subjects such as LSP courses at least, we have understood the difference between the concepts of employability and employment, we can better grasp the reasons behind an apparently low domain-specific employment in the case of tourism graduates from BabeșBolyai University:

\begin{abstract}
"The curricular process may facilitate the development of prerequisites appropriate to employment, but does not guarantee it. Hence it is inappropriate to assume that a student is highly employable merely on the grounds that they have experienced a particular curriculum. The graduate exhibits employability in respect of a job if they can demonstrate a set of achievements that are relevant to the job" (Knight \& Yorke, 2003, p. 4).
\end{abstract}

If we accept Knight and Yorke's standard definition of employment as "a set of achievements, understandings and personal attributes that make individuals more likely to gain employment and be successful in their chosen occupations" (Knight \& Yorke, 2003, p. 5), we can see why employability gives the measure of a potential future graduates attain (or not) in their efforts to succeed professionally. Knight and Yorke go on to detail the constructs that demonstrate employability seen as: 
- $\quad$ “Employability demonstrated by the graduate actually obtaining a job.

- Employability as the student being developed by their experience of higher education (i.e. it is a curricular and perhaps extracurricular process).

- Employability in terms of personal achievements (and, implicitly, potential)" (Knight \& Yorke, 2003, pp. 3-4).

The role of higher education institutions in shaping students' employability is mostly visible in their strategy to correlate the overall learning experience with students' potential on the one hand and market mobility on the other hand. The fact that this strategy cannot offer "onesize-fits-all" recipes is confirmed by studies dedicated to measuring university approaches to graduate student employability, which conclude that "there is little evidence of systematic thinking about how best to do it, let alone any model that can be badged as 'best practice' and adopted wholesale" (Little qtd. in Ryan, 2013, p. 211).

With respect to the content of LSP syllabi, one particular aspect which could constitute a starting point for triggering a change of paradigm is the role of students as full participants rather than consumers of education and training, as agents involved in authoring "specificity" rather than receiving it (Gollin-Kies, Hall \& Moore, 2015, p. 124). Specialists recommend seeing the needs analysis stage as a "continuous process, taking place before, during and even after course delivery" and the LSP course as the context in which "[n] eeds, wants and methodology are continuously negotiated" (Gollin-Kies, Hall \& Moore, 2015, p. 89). At an institutional level (the case of BabeșBolyai University), however, due to the limitation in the number of hours/LSP class ( $2 \mathrm{~h} /$ week) and of specialised language learning path (2 semesters) as well as to the fact that LSP classes are generally taught to first year undergraduate students, the constant (re)negotiation of content and intended outcomes could generate partially unreliable or inconsistent results. Nonetheless, what LSP teachers aim, following discussions and negotiations with various stakeholders, is to prepare students for performing in a socio-professional context when communication in a foreig $n$ language is involved. That this performance ${ }^{1 i}$ is technical or not is secondary to the LSP teachers' focus on the students' ability to communicate the specificity of their (future) workload, on the "underlying traits that produced the performance, i.e., communicative competence, or (...) specific purpose language ability" (Douglas, 2000, p. 27).

Teaching and testing specific purpose language ability are, as the present study shows, important as they indicate, to a certain extent, the potential to perform professionally as well as beyond or outside the vocational field. They are part of the larger second language (L2) learning

1 'Depending on the field, the 'performance' may involve anything from solving a computing problem; to researching a product and its market in order to prepare a strategic plan; to setting up a task force to investigate and report on cost management issues (...). Clearly, tasks like this are able to introduce students to the specific 'tools' of a particular workplace and provide practice at using these 'tools'" (Gollin-Kies, Hall \& Moore, 2015, p. 11). 
experience, ${ }^{2}$ which, according to Dörnyei's motivational self-system model, is one of the three sources of motivation for achieving success in foreign language acquisition.

\section{THE STUDY}

The focus of this paper is centered on the results of an extensive study the authors carried out in 2019 among graduates having specialized in tourism or cultural tourism at Babeș-Bolyai University and among employers from the hospitality industry. The core of the research revolved around analyzing the professional and personal impact of having taken a specialized foreign language course (in our case English for Tourism) and comparing the students' expectations about its usefulness on the labor market with the subject-specific or generic expectations that tourism companies have of their job candidates.

The authors have extended the research scope to all the actors involved in this academic-professional context: undergraduate and graduate students, postgraduate (M.A.) students, tourism specialism (content) teachers, and last but not least, representatives of Cluj-based tourism companies that could illustrate the needs of the labor market which will most likely hire some of these young people educated at Babeș-Bolyai University. All parts involved provided an accurate view of the usefulness of English nowadays as a lingua franca in such an internationalized and multicultural domain as the hospitality industry. This panoramic view of the study given by the teaching, learning, testing and practising aspects of English for Tourism has brought forth a better understanding of what should $\mathrm{ESP}^{3}$ teachers improve in their educational offer to facilitate students' professional success.

In view of the magnitude of the study, for practical purposes, the authors have presented their findings in separate articles. ${ }^{4}$ The present one focuses on synthesising the results of the survey addressed to the graduates of the Faculty of Geography and the Faculty of History and Philosophy that have specialized in tourism along with the results from the survey directed toward prospective tourism employers represented by hospitality industry companies from Cluj county.

2 The L2 leaning experience "reflects reflects contextual issues such as the curriculum, teacher and peer group pressure" (Woodrow, 2017, p. 241).

3 ESP - English for Specific Purposes.

${ }^{4}$ A previous article dealt with the results of the surveys dedicated to the B.A. and M.A. tourism students (Mihele \& Păcurar, 2019). 


\section{DATA COLLECTI ON AND ANALYSIS}

In order to find out what the perceptions of the (already employed) graduates and those of the tourism companies' representatives are regarding the usefulness of possessing foreign language skills, the two authors adopted a quantitative approach for their research by compiling two questionnaires, one in English for the former students, and one in Romanian for the domestic employers. The first questionnaire aimed at measuring the impact that formal academic English language instruction has had on tourism graduates from the afore-mentioned faculties belonging to BabeșBolyai University. The second questionnaire interrogated the views of the hospitality companies based in Cluj county which collaborate with the university within the framework of the specialized internships programs dedicated to the better training of our students for their future jobs.

On this occasion, the authors would like to acknowledgethe invaluable help given by Reader Iuliu Vescan, Ph.D., from the Faculty of Geography, Babeș-Bolyai University, who suggested adding the employers' dimen sion to our study and who facilitated the contact with these tourism companies. His ready help was much appreciated, as it confirmed the multilateral concern for the improvement of our students' training, coming from both specialism professors and from specific purposes language instructors.

To collect the opinions of both employees and employers, for the research were used two quantitative questionnaires completed on-line using the platform Google Forms. Both groups received via email the web addresses of the questionnaires. The time frame allotted for the completion was of four weeks, from April 15 th to May 12 $12^{\text {th }}, 2019$ for the graduates' form. The employers' form took a longer time to complete, from J une $1^{\text {st }}$ to October $1^{\text {st }} 2019$ due to the fact that the companies, most probably caught in the turmoil of the high season, took a longer time to respond to our research requests. Both groups were informed of the anonymity of the data collecting process and of the fact that the results were to be used in academic research studies.

The survey addressing university graduates consisted of 14 multiple choice questions and three open ended ones, thus adding a partial qualitative nature to its predominantly quantitative core. The second one, directed toward tourism companies, was based on 13 multiple choice queries.

\section{SAMPLI NG}

The data from the first survey were drawn from a number of 30 responses coming from former graduates of the Faculty of Geography who have specialized in the geography of tourism and those of the Faculty of History who have specialized in cultural tourism at Babeș-Bolyai University. In terms of sociometric measurements of the respondents' characteristics, the vast majority were female (76.7\%), a logical consequence of the fact that 
both our B.A. and M.A. tourism students were female in a proportion of $3 / 4$ as compared to their male colleagues. More than half of the graduates were aged between 25-30, making our sample group one of noticeably young people. They are at the beginning of their career, when the details of their academic instruction received during English courses is still fresh in their mind, so that it can be easily contrasted with its pragmatic use at the workplace. Only seven out of 30 respondents were aged between 21 and 25 , probably recent graduates from the M.A. tourism programs, while four people were aged between 30 and 35 .

The fact that our graduates are still in their first ten years of professional experience $(70 \%$ of them mentioned that no more than five years lapsed since their last formal academic instruction) may explain the partially unexpected results we have received to two queries regarding their current and previous job. Related to the previous job that they had had before taking the question naire in 2019 , half of respondents indicated that they had worked in tourism. They were hired as receptionists, front office managers, tour guides, travel agents, travel counselors, reservations agents, kitchen helpers, waiters, event coordinators. Later on, for their current job, out of the 30 Tourism graduates, only eight mentioned that their employment still belongs to the domain they have licensed in. This small group mentioned working mostly for hotels and travel agencies in positions such as: breakfast supervisor, hotel receptionist, travel agent, tour guide, event planner, key account executive. Their other colleagues who took the survey mentioned working in other fields of activity, predominantly in the service sector.

This drop of interest in the chosen domain, from half of them to less than $1 / 4$ in a relatively short time span draws our attention to the discrepancy between the students' desire to study tourism and a reluctance to choose it as their career path. Considering that from our respondents, 14 own a B.A. degree, 14 have an M.A. degree and one even holds a Ph.D. degree, yet there are fewer management positions in their current job choices, one could wonder if they have simply decided to changetheir field in search of professional satisfaction. A revealing detail given by the responses regarding the current employment could suggest an answer in what concerns the attractivity of working in the Romanian hospitality industry. Out of the 30 graduates, nine mentioned that they were currently living and working abroad - three of them in the United States of America and one in each of these (mostly Western) countries: Ireland, Germany, the U.K., Italy, Poland and Turkey. Another interesting explanation for this discrepancy could come from fact that our graduate students are situated in what Ulrich Teichler would call the extended transition period between the realm of education and the more factual reality of the employment domain:

'The process of transition from education to work turned out to be a
complex and protracted affair, possibly lasting even more than ten years.
[...] It is generally assumed that the process of transition has become longer
notably as the consequence of greater employment problems, increasing
flexibility and diversity of educational and training provisions, a decreasing
of 'stability' or increasing of 'flexibility' of careers, and finally of a greater
inclination on the part of young persons to accept trial and error as well as 
occupational mobility in search, provisional employment and various phases of education and training in order to reach position and work assignments which match with their expectations. Moreover, the growing life-long learning activities and other factors could restructure the relationships between pre-career education and employment. Consequently, any recent attempt at measuring the relationships between education and employment has to take into account the extended period" (Teichler, 1999, p. 228).

When it comes to the second questionnaire dedicated to prospective tourism employers, the representatives of only ten companies answered our inquiry. These companies were among a limited set of companies that collaborate with the Faculty of Geography in the formal context of internship programs meant to help the students practice their knowledge and silks in real life work situations. The fact that the authors of the study could reach these Cluj county-based hospitality companies only in the mediated manner mentioned above could explain the low number of respondents. From these 10 prospective employers, $40 \%$ represented hoteliers, another $40 \%$ travel agencies and $10 \%$ were indicative of an event organizing company and a guided tour organizing company, respectively.

In what the profile of these companies is concerned, seven of them mentioned that their employees carried out their jobs in Romania and only three of them indicated both Romania and foreign countries were places where their staff had to perform. However, when it comes to the interaction with the clients, an overwhelming majority (90\% of them) indicated that their customers were both Romanian and foreign clients, therefore their employees should have been ready to know how to interact with both categories. These two aspects will prove to be relevant later on in our analysis as we explore the attitude that employers have regarding the English language skills that the members of their teams should prove for a proper customer care and interaction with international business partners.

\section{MAI N FI NDI NGS}

\section{The acute need of English for both hiring and working procedures}

The first important result of our study is connected to the undeniable importance of having good foreign language skills when working in tourism. The prevalence of English goes almost undisputed with the employers, while the graduates emphasize how helpful their academic English instruction was for obtaining a job, a fact confirmed by the companies, and also for using this language on a frequent basis at work to perform several specific tasks.

As a background for their potential and actual employment in tourism, the graduates confess in a large majority that $73.3 \%$ of them own a language certificate to prove that they have the necessary foreign language skills for getting hired in such a dynamic domain. When it comes to the level of proficiency it certifies, $90 \%$ of them indicated that they have at least level B2 (intermediate) if not even more: $40 \%$ are at level B2, 30\% are at level C1 (advanced) and $20 \%$ are at level C2 (expert). The results 
point to two different aspects. The first one is that most of them have studied English at university for a long time (6 or more semesters as indicated by a total of $67 \%$ of respondents), thus benefitting from reasonable training and time for sufficient skills to reach this level. From a previous survey addressed to the $1^{\text {st }}$ year students, we know that at the beginning of their academic track a similar percentage of students - $63 \%$ indicated they are at level B1-B2. Unfortunately, since their graduation, the internal language policy has regulated the limitation of the number of semesters dedicated to studying a compulsory foreign language to only 2 , a fact that may negatively impact the progress towards a prospective proficiency level.

In their turn, asked if the knowledge of a foreign language was required within their company, the employers, with large majority of $70 \%$ answered that their future employees needed English and ideally another foreign language, as indicated in Figure 1. This aspect points out the need for more than one language in the hospitality industry, probably the most international sector of the economy. It is to be noted that the respondents did not pick at all these extra options: "Future employees will need a foreign language, no matter which one", "Future employees will need foreign languages only rarely", and "Future employees will not need foreign languages at all."

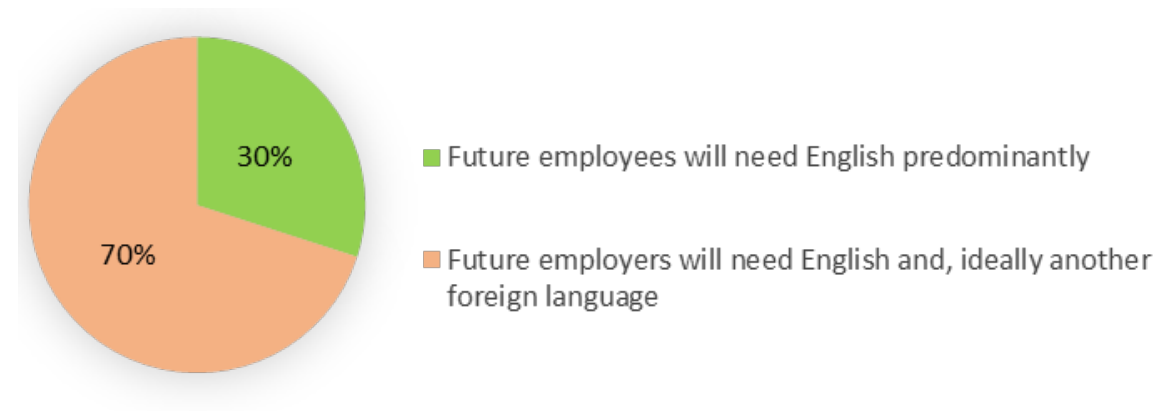

Fig. 1. The need for (a) foreign language(s) as mentioned by prospective employers

Still $70 \%$ indicated that both written and spoken English were needed, just three out of ten having mentioned that they required only spoken English. This goes against the grain of what students and some teachers usually suppose: that in such a direct, face-to-face encounter domain as tourism, mostly the speaking skills should be mastered. When asked what other language future candidates should ideally know, the tourism employers indicated that they searched for speakers of German (six out of ten), then experts in Spanish (two out of ten) and one preferred Italian speakers, as illustrated in Figure 2. We suspect that these choices could be connected to the nationality of the incoming travellers they welcome or maybe to the outbound destinations targeted by Romanian tourists. We should also mention that no employer has chosen as necessary the following foreign 
language options: Russian, Hungarian, a Scandinavian language (Norwegian, Danish, Swedish), an Asian language (Japanese, Chinese, Korean) or a language from the Middle East (Turkish, Arabic, Hebrew). The usage frequency of such linguistic skills in the workplace is considerably high according to the Cluj based tourism companies. In order to perform their job requirements, prospective employees should use a foreign language frequently, as indicated by $60 \%$ of respondents, or even all the time as mentioned by $30 \%$ of the companies' representatives.

Not only should employees use English frequently to perform their professional tasks, but first and foremost, having foreign language skills is a necessary requirement in the recruitment process. Graduates are already aware of that as we have seen before (21 out of 30 say that Englishlanguage instruction was important in getting their job) and, in their turn, the recruiters have several ways of checking this aspect. Most of them $(60 \%)$ ask candidates to pass a part of the interview in a foreign language, while others either check the candidates' CVs or ask them to present a language certificate. Surprisingly, $20 \%$ of recruiters just take their candidates' word in this respect. The proficiency level most of them require is B2 in a proportion of $60 \%, 20 \%$ asking for just B1 and $10 \%$ demanding level $\mathrm{C} 1$. This finding correlates well with the level the graduates can certify they have, which is indicative of the finely tuned preparation for the labor market that young people have nowadays.

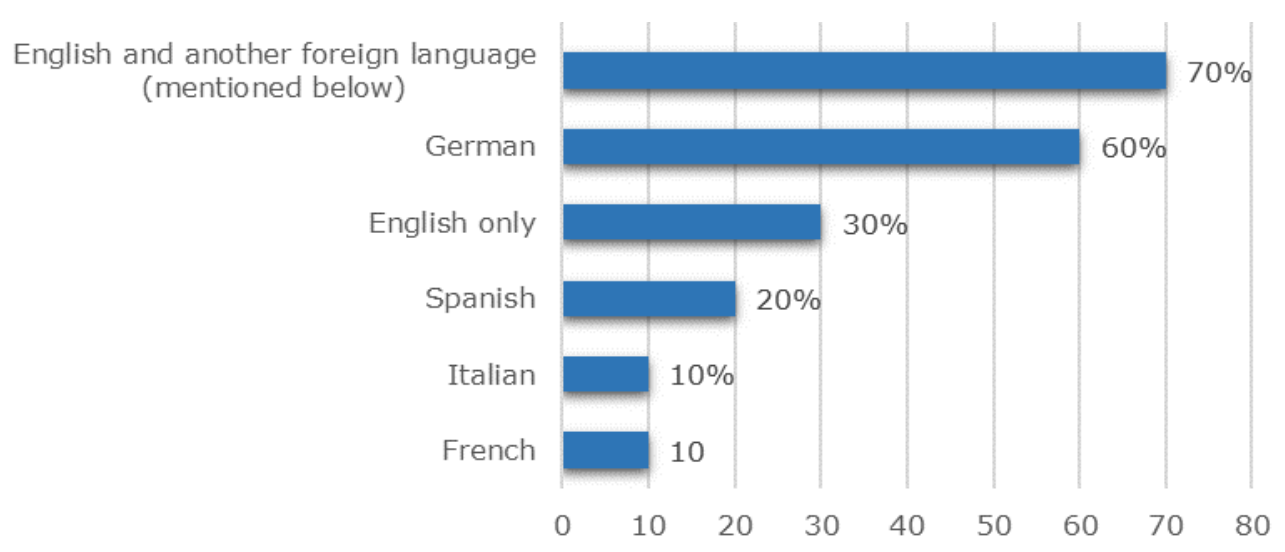

Fig. 2. The foreign languages required by employers

This knowledge of what the market requires can easily come from the work experience some of our young graduates already possess. As noted in Figure 3, asked if they use English as part of their professional activity, the overwhelming majority said yes ( 26 out of 30 ). Nevertheless, irrespective of the nature of their job, they mention that using English is an essential part of their professional life. This does not come as a surprise, knowing how ubiquitous English is nowadays, this language being especially needed by the respondents who have emigrated and who are currently living in an English-speaking country. 
As can be seen in Figure 4, graduates' and employers' answers are similar also when it comes to the type of activities and tasks for which English is needed. In the order of importance, the young graduates mentioned that they use English: (1) to write e-mails; (2) to write other job-related materials (memos, analyses, reports, etc.); (3) to take phone calls and to read job-related materials; (4) to talk to clients face-to-face.

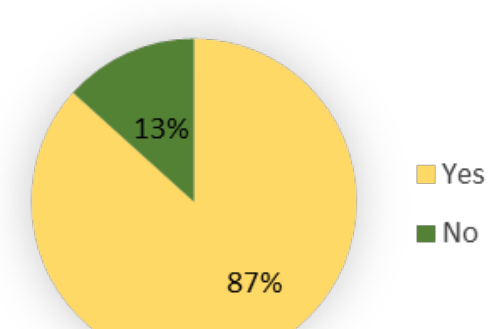

Fig. 3. The usage of English as part of our graduates' professional activity

Other options mentioned by just a few graduates for their job activities conducted in English include: "Quality checks of medical papers," "Writing medical papers," "Teaching," "Research," "Curating" and "Not applicable." From their answers, we can notice that they indicate using predominantly written English, not spoken English as it is commonly expected in tourism. However, we should keep in mind that most of them are currently working in other fields and not in the hospitality industry where a direct interaction with international clients is usually implied.

As an example of the qualitative dimension of our study, we have investigated how relevant the graduates' university ESP courses were by asking them to say a few words about the relevance of their English language academic instruction for their daily personal and professional activities. This is what two students wrote:

"I use English every day and I am happy that I get [sic!] the chance to study especially English for Tourism because I work in the hotel industry, so it is very important to have a good communication with my guests." [s.1 $]^{5}$

"As a travel agent I need a fluent English to write emails and have phone conversations with my clients. And the English that I studied at university helped me a lot!" [s.2 ${ }^{6}$

5 [s.1] = student 1 - we have decided to quote the students' words accurately, as they have been written, mistakes included, to illustrate their real usage of English.

6 [s.2] = student 2 . 
ELENA PĂCURAR, ROXANA MIHELE

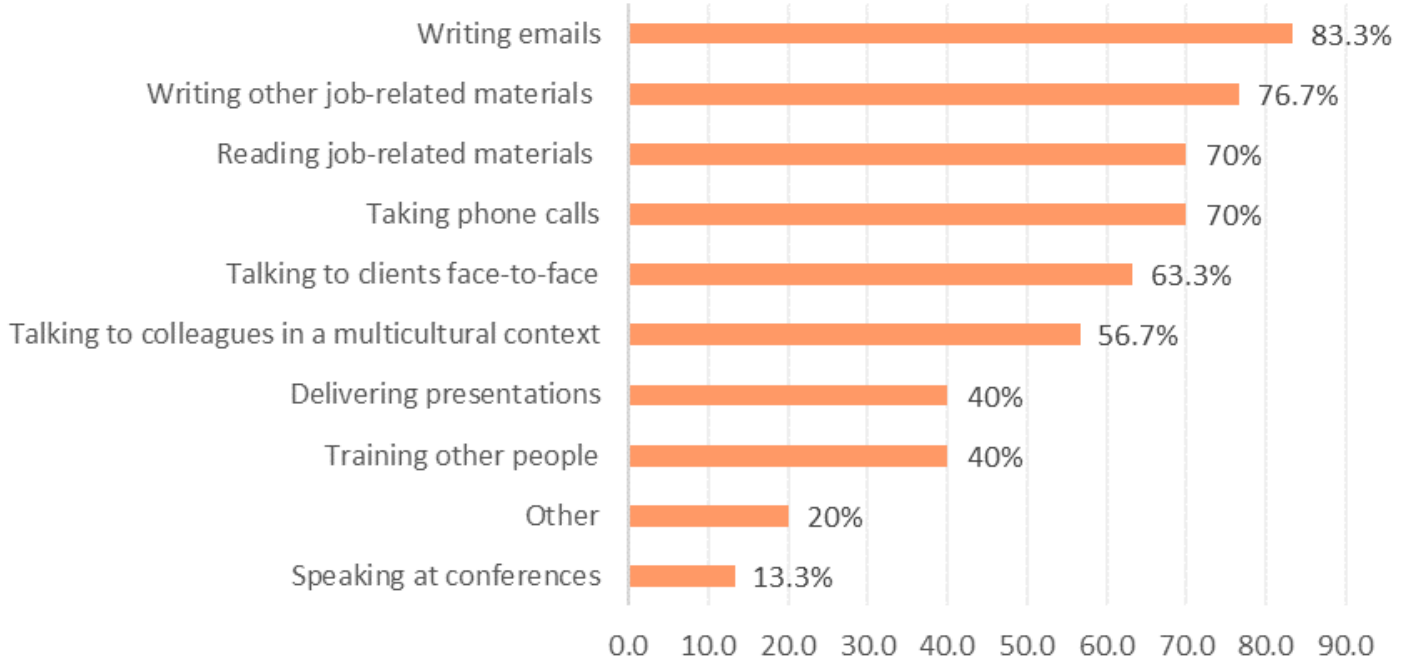

Fig. 4. The activities in which graduates use English at work

In their turn, the representatives of the trade mention that the situation s in which their employers are more likely to use English often or very often are: (1) for reading emails and descriptions of tourist attractions in English rather than answering emails and writing official letters, (2) for processing phone and on- line reservations in English, (3) for carrying out conversations with the tourists in English and for giving explanations and solving specific problems, and (4) for speaking face-to-face with the customers. On the employers' side, we can notice a slight emphasis of the productive skills, especially speaking. This could be accounted for by the pragmatic usage of the language in tourism vs. other domains from the service sectors that our graduates mentioned activating in.

\section{The employers' inclination for going beyond the academic chartered skills and know ledge}

One surprising finding of our study is linked to the manner in which tou rism employers select their future staff. In the questionnaire devised for the hospitality industry companies in Cluj county, one of the most interesting aspects concerned the selection procedure that employers would use; namely the criteria they would favor during the hiring process. Obviously, the focus of the research was on whether foreign language skills in general, and English mastery in particular, were important for the companies. These specific answers would then correlate with the perception the graduates had regarding the importance and usefulness of formal ESP instruction. As we have mentioned above, there is a tremendous importance attached to being a good speaker of English by both categories, tourism employers and employees alike. To this aspect, we can add the need to have professionals who would master more than just one foreign language, as specified by the companies' representatives. 
However, when asked about the importance of other components for the professional profile of a potential employee, the employers' answers confirm our theoretical investigations. First of all, on an importance rating scale they have mentioned appreciating in their prospective candidates the possession of certain specific competences such as the customer care, phone speaking abilities, etc. and their involvement in extra-curricular activities. Graduates' specialization ranks second and the previous professional experience is considered less important. This comes contrary to the stereotypical belief that the labor market is a place where one's education and professional experience would dictate who gets the job and who doesn't. Half of the respondents qualified the grades obtained in college as "less important." The theoretical knowledge or the (academic) skills obtained at university or at a previous job are also considered of secondary importance.

Asked about the abilities and the competences they would prefer in a potential candidate for a job in their company, the employers prioritize a good communication in the mother tongue, having initiative, having problem-solving skills, and having leadership skills. A series of abilities like a good communication in foreign languages, teamwork, creativity, and a good time management were ranked second. Obviously this correlates with the above-mentioned hiring criteria by emphasizing the need for adaptable, creative and flexible people who have no trouble learning new things quickly, who know how to communicate efficiently with customers in a domain dedicated to serving them. What is expected of the graduates is to have a proactive attitude, where they could spot potential problems even before they occur, where they would not be afraid to take action without waiting for a cue from the manager, where they would be mature enough to know how to handle time and customers' wishes.

In terms of professional and personal qualities that future members of staff should have, seven out of ten respondents underlined their utmost preference for candidates that possess first of all intellectual curiosity, then self-reliance and maturity. Other qualities which were deemed as "important" by five respondents and "very important" by the other five were: the capacity to adapt, a desire for group/professional community integration, professionalism and the capacity for self-assessment and reflection. What college teachers can learn from these findings is that when preparing the students for their future job, they should keep in mind that they should prepare them for life as well. We can all recognize the fact that living in a fast-changing world necessarily implies that in order to survive and thrive professionally we should be very flexible, we should embrace the new no matter how uncomfortable it is (as we have already seen with the need for on-line teaching and e-learning brought forth by the Covid-19 pandemic). Most importantly, we should be aware that students need to be prepared for the yet unknown jobs of the future, not only for today's jobs, which may well disappear in the next 10-20 years. As such, we as teachers should focus less on the domain specific skills we are currently embracing and try more transversal, core skills. We should teach our students critical thinking, we should show them how to boost their creativity, how to keep 
an open mind that can make connections between various domains. Their professional future will be dependent upon these.

\section{The role of English in building a well-rounded set of both personal and professional attributes required by employers}

One thing that could go to the credit of what the university instruction has done well so far is the fact that in providing students with foreign language courses, the academia has given them not only specific language skills targeted for the specialism but also empowered them with self-confidence and a sense of belonging to a larger community. In this sense, it meets the employers' demand for tourism specialists that can master English and use it with confidence in their frequent interactions with international clients or business partners.

When asked in the questionnaire about the changes in their lives, about the way they saw themselves and the way others perceived them, the graduates mentioned strongly positive consequences of them having studied English (Figure 5). Beyond the language skills much needed for a job nowadays in basically any field, most of the respondents mentioned that using English helped a lot with their self-esteem and level of confidence. They strongly disagreed with the fact that using English has negatively affected the way other people perceived them or the way they see themselves. This tells us that both the graduates and the society at large see English as an advantage in the professional fast track and as a source of personal empowerment. "It made [me] more confident!" [s.3 [ ${ }^{7}$ admitted a respondent in an answer to an open-ended question about the relevance of their academic English instruction. To add to this dimension, 28 out of 30 respondents agreed or strongly agreed that using English makes them feel like a member of a larger community. This best illustrates the theories of the internal mechanisms triggered by second language students' instrumental and integrative motivation ${ }^{8}$ for improving their communicative skills. We should mention that no respondents picked the options "strongly disagree" or "disagree" when it came to the statements "Using English helps with my selfesteem and level of confidence" and "Using English makes me feel like a member of a larger community." Also, nobody agreed that "Using English has negatively affected the way other people see me."

When it comes to how studying English in the higher educational system has perfected their professional attributes, an overwhelming majority of graduates admit that English was important in the recruitment process. Next, they informed us that the academic language instruction was important in their professional routine and that they used domain specific

\footnotetext{
7 [s.3] = Student 3 .

8 "If you are learning a language primarily for a purpose like getting a job or fulfilling an academic requirement you are affected by instrumental motivation. Integrative motivation has to do with wanting to be accepted by another community. (...) integrative motivation is about acceptance and some form of membership in a language community" (Leaver, Ehrman \& Shekhtman, 2005, p. 104).
} 
vocabulary (English for Tourism) in their activities. We have also learned from the survey that graduates have complemented the domain specific English vocabulary learnt at courses with specific purpose vocabulary acquired in the workplace. This leads us to a further aspect that they have mentioned - the importance of lifelong learning for continuously improving communicative skills and specific purpose language abilities.

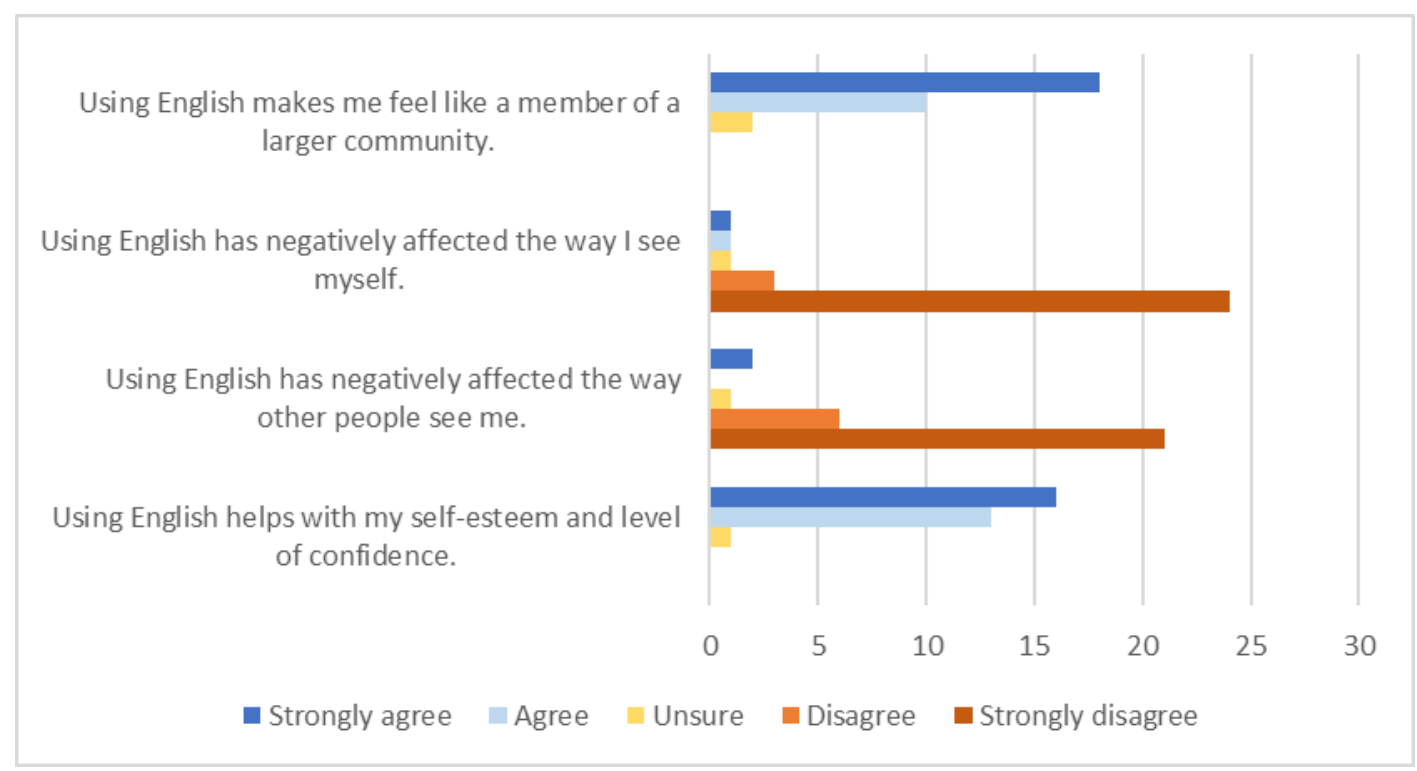

Fig. 5. The personal benefits of having studied English in college

The questionnaire has shown us that they use English even outside the professional context. For young people nowadays, being connected to the Global Village and its latest trends is a must; therefore they use English mostly for entertainment (listening to English language music bands/ artists, for watching movies without subtitles, for communication on social media, for reading books, magazines, etc.), for personal travelling purposes and for keeping in touch with friends and acquaintances from other countries. We can notice that even this informal usage of the language can contribute to turning these young people into well-informed and wellconnected individuals, in touch with the latest changes and novelties - the ideal hospitality industry employees.

\section{A FINAL NOTE AND CONCLUSIONS}

Both as a generator of qualified workforce and as an area with a proven touristic potential, Cluj county is an interesting case study for a possible discussion of further development opportunities in the tourism industry and in the field of tourism education (whether we speak of tertiary or higher education). Featuring as one of the "top eight" counties for domestic and international visitation alike (together with Constanța, Brașov, Bucharest- 
Ilfov, Mureș, Prahova, Bihor, and Sibiu), Cluj is considered one of the prominent high performing tourism counties in Romania. However, Cluj county cannot be identified in the list of national associations currently functioning as DMOs (destination management organisations), as shown in Table 1 below. Defined as "a legal entity, which carries out the policy of the tourist development of the destination, including the destination marketing policy, in accordance with the legal provisions in force" (OECD Tourism Papers, 2020, p. 23), a DMO brings together representatives from both the public and private sector to align policies and strategies for a more comprehensive development of the existing tourism potential of an area.

Table. 1. Associations in Romania that currently work as a DMO

\begin{tabular}{|c|c|c|}
\hline No. & Association & County \\
\hline 1 & The Association for Tourist Promotion and Development Brasov & Brasov \\
\hline 2 & Poiana Brasov Association & Brasov \\
\hline 3. & Protourism Association Fagarasi Country, Sibiu & Sibiu \\
\hline 4. & The County Association for Tourism Sibiu & Sibiu \\
\hline 5. & The Intercommunity Development Association Bistrita Nasaud & Bistrita Nasaud \\
\hline 6. & The Intercommunity Development Association Harghita & Harghita \\
\hline 7. & The Intercommunity Development Association Sarata Monteoru & Buzau \\
\hline 8. & The Intercommunity Development Association Buzau Landing & Buzau \\
\hline 9. & The Association for Tourist Promotion and Development & Prahova \\
\hline 10. & The Ozane Valley Association for Tourism Promotion and Development & Neamt \\
\hline 11. & The Association for Tourism Promotion and Development & Neamt \\
\hline 12. & The Association Microregion Hateg Country - Land of the Forest People & Hunedoara \\
\hline 13. & The Association for Tourism Promotion Oradea and Region & Oradea \\
\hline 14. & The Association Management Agency of Bihor Destination & Bihor \\
\hline 15. & The Association for Tourist Promotion and Development in Timis County & Timis \\
\hline 16. & The Association Visit Mures & Mures \\
\hline 17. & The Tourism Association Covasna & Covasna \\
\hline 18. & The Association for Tourist Destination Management - Danube Delta & Tulcea \\
\hline 19 & The Association Danube Moldova Noua & Caras Severin \\
\hline 20 & Mamaia Constanta Private Organisation (OPMCTA) & Constanta \\
\hline 21 & The Association for promotion and development of tourism "Acasa la Brancusi"(home of Brancusi) & Gorj \\
\hline
\end{tabular}

Source: OECD, 2020, p. 37

The collaboration between the various entities (private, public sector and DMOs) often results in shared studies and investigations of the current state and the potential for tourism development; one of the recent SWOT analyses dedicated to Romanian tourism contains useful information for all parts involved. Six are the issues considered strategic for Romanian destination management, among which: "the tourism asset base, tourism employment and skills deficit, product differentiation and diversification, transport and access infrastructure, tourism and the public policy environment and access to EU funding" (OECD Tourism Papers, 2020, p. 31). Not surprisingly perhaps, as the percentage of qualified staff currently working in domestic tourism revealed by our study confirms, two of the recurring items included in the list of weaknesses are the skills gaps of those employed in domestic tourism and the scarcity of qualified staff. A 
possible solution to this strategic problem could be furnished, as the OECD report informs, by the existence and involvement of DMOs:

"A particular concern reported in this respect is the number of Romanians leaving the country to work in tourism or other sectors in neighbouring countries. The high number of tourism workers in the informal economy in Romania was also noted. It is clear that there is an urgent education and skills issue to be addressed in the Romanian tourism industry. Continuing poor skills levels will undermine the visitor experience and ultimately undermine the value for money associated with the Romanian tourism offering. The promotion of existing training programmes, combined with the development of new training programmes, is required. (...) These are matters that should be addressed within a new sub-national network of DMOs" (OECD Tourism Papers, 2020, p. 33).

Such organisations that could go beyond the immediate range of action (marketing and promotion) and would engage the participation, expertise and contribution of higher education institutions are seen as hubs for further development and proactive thinking. In turn, universities might benefit from first-hand information about and access to the current mapping of the labour market, its expectations, needs and, what is more important, its opportunities for innovation. Our study has shown how an opening of the curriculum from the (narrow) domain-specific content targeting employment towards the (wider) range of transversal learning outcomes targeting employability could be considered a relevant way to anticipate (rather than react to) change in the field of tourism education in Cluj county.

\section{References}

Douglas, D. (2000). Assessing Languages for Specific Purposes. Cambridge: Cambridge University Press.

Gollin-Kies, S., Hall, D.R. \& Moore, S.H. (2015). Language for Specific Purposes. New York: Palgrave Macmillan.

Knight, P.T. \& Yorke, M. (2003). Assessment, Learning and Employability. Milton Keynes: Society for Research in Higher Education \& Open University Press.

Leaver, B.L., Ehrman, M. \& Shekhtman, B. (2005). Achieving Success in Second Language Acquisition. Cambridge: Cambridge University Press.

Mihele, R. \& Păcurar, E. (2019). Autonomy and Accountability in Curricular (Re)Design: Aligning the Intended Learning Outcomes with Students' Expectations. Romanian Review of Geographical Education, 8(2), 38-57. DOI: $10.23741 /$ RRGE220193

OECD Tourism Papers (2020/01). Operationalisation of Destination Management Organisations in Romania. Retrieved 22 June 2020, from https://www. oecdilibrary.org/docserver/9074fc18-

en. pdf $?$ expires $=1594883168 \& i d=i d \& a c c n a m e=$ guest $\&$ checksum $=45 \mathrm{CE} 339 \mathrm{D}$ B28A044COAAF57EF981E8E00. 
Riley, M., Ladkin, A. \& Szivas, E. (2002). Tourism Employment. Analysis and Planning. Clevedon, Buffalo, Toronto, Sydney: Channel View Publications.

Ryan, J. (ed.) (2013). Cross-Cultural Teaching and Learning for Home and International Students. London, NY: Routledge.

Teichler, U. (1999). The Contribution of Education and Training to the Employability of Youth: Changing Concerns, Debates and Measures. Preparing Youth for the 21 $1^{\text {st }}$ Century: The Transition from Education to the Labour Market. Proceedings of the Washington D.C. Conference, 23-24 February 1999. OECD, Paris 1999, 215-262.

UNWTO Report (2019). Retrieved 14 July 2020, from https://www.eunwto.org/doi/pdf/10.18111/9789284421213.

Woodrow, L. (2017). Motivation in Language Learning. In Breeze, R. \& Sancho Guinda, C. (eds.), Essential Competencies for English-medium University Teaching (pp. 235-249). Cham: Springer. 